\title{
Inactivation of the mouse Brca1 gene leads to failure in the morphogenesis of the egg cylinder in early postimplantation development
}

\author{
Chia-Yang Liu, Andrea Flesken-Nikitin, Shang Li, Yingying Zeng, and Wen-Hwa Lee ${ }^{1}$ \\ Center for Molecular Medicine/Institute of Biotechnology, The University of Texas Health Science Center at San Antonio, \\ San Antonio, Texas 78245 USA
}

\begin{abstract}
$B R C A 1$ is proposed to be a tumor suppressor gene. To explore the biological function of $B R C A 1$, a partial deletion (amino acids 300-361) of mouse Brca1 exon 11 was introduced into the genome of embryonic stem (ES) cells by homologous recombination. Mice carrying one mutated allele of Brca1 appear normal and are fertile up to 10 months of age without any sign of illness. However, no viable progeny homozygous for the Brca1 mutant allele were obtained. Detailed analysis of large numbers of embryos at different stages of development indicated that the homozygous mutant concepti are severely retarded in growth as early as embryonic day 4.5 (E4.5) and are resorbed completely by E8.5. Although the homozygotes at E5.5-E6.5 are able to synthesize DNA and display distinguishable embryonic and extraembryonic structures, they fail to differentiate and form egg cylinders. Consequently, they were unable to form primitive streaks and undergo gastrulation. Consistent with these in vivo results, blastocysts homozygous for mutated Brca1 alleles are at a considerable disadvantage when grown in vitro. These observations suggest that Brca1 has an important role in the early development of mouse embryos.
\end{abstract}

[Key Words: Brca1 gene; gene targeting; mouse embryogenesis]

Received May 3, 1996; revised version accepted May 30, 1996.

Hereditary breast cancer is characterized as an early-onset, bilateral disease and is associated with other tumors of ovarian, endometrial, and prostate origins (Tulinius et al. 1992; Anderson and Badzioch 1993; Sellers et al. 1994). The heterogeneity in breast cancer suggests that the manifestation of multiple genetic factors intertwines with environmental factors, such as hormones and diet, that modify expression of the phenotype. At the molecular level, breast tumor development is thought to result from mutations of several growth regulatory genes. The $B R C A 1$ gene is mutated in the germ line of a subset of families with inherited breast cancer, and loss of the remaining wild-type allele is often found in tumor tissues (Hall et al. 1990; Smith et al. 1992; Miki et al. 1994). This recessive nature of $B R C A 1$ fits with the properties of human tumor suppressor genes (Riley et al. 1994).

$B R C A 1$ mutations are associated with $45 \%$ of familial breast cancer, which accounts for $\sim 10 \%$ of the total number of these neoplasms. However, they are rarely linked with sporadic cases (Futreal et al. 1994). Therefore, the role of BRCA1 in the pathogenesis of $95 \%$ of breast cancer is unclear. Interestingly, the $B R C A 1$ gene

${ }^{1}$ Corresponding author. product, which is normally a nuclear protein, is aberrantly mislocated in the cytoplasm of most breast tumor cell lines (Chen et al. 1995). Although the molecular mechanism for the failure of nuclear transport is not known, these findings suggest that BRCAl may be involved in many breast cancers, sporadic as well as familial.

$B R C A 1$ is a large gene spread over $\sim 100 \mathrm{~kb}$ of the genome. It consists of 24 exons and encodes a nuclear phosphoprotein of 1863 amino acids with a molecular weight of $\sim 220 \mathrm{kD}$ (Chen et al. 1995, 1996). BRCAl is a novel protein with an amino-terminal ring finger motif similar to those found in other proteins that interact with DNA, RNA, or proteins (Miki et al. 1994). The mouse BRCA1 homolog, Brca1, was characterized recently. The predicted Brcal gene product shares $\sim 58 \%$ amino-acid identity with the human protein, and the mRNA expression patterns in mice and humans are also quite similar. Interestingly, Brca1 mRNA expression in mouse mammary gland involution parallels its differentiation, suggesting an important regulatory role for Brcal in tissue proliferation and differentiation (Lane et al. 1995; Marquis et al. 1995).

To understand the physiological function of Brca1 and study its role in breast and ovarian carcinogenesis, we 
established mutant Brca1 $|+|-\mid$ mouse lines using gene targeting in embryonic stem (ES) cells. Mice lacking one wild-type allele of the Brca1 appear normal and are fertile until 10 months of age. However, Brca1 $|-/-|$ mutants die during early embryogenesis. Histological examinations of early concepti and genotyping after fixation by microdissection-polymerase chain reaction (MDPCR) demonstrated that Brca1 (- / - ) mutant embryos are growth-retarded as early as embryonic day (E4.5). They form embryonic and extraembryonic tissues but develop into severely disorganized masses incapable of forming egg cylinders at E5.5-E6.5. The embryos are resorbed completely by E8.5. These results reveal an important role for the Brca1 gene in early mouse development.

\section{Results}

\section{Targeted mutation of the mouse BRCAl homolog}

For genetic ablation of mouse Brca1, exon 11 was chosen as the target because its counterpart in the human $B R C A 1$ is the largest coding exon (3425 bp) and is frequently mutated in families with histories of breast and ovarian cancer. Mouse Brca1 was obtained by screening a $129 /$ Sv-derived genomic library with PCR-amplified DNA from exon 11 of the human BRCA1.

The targeting vector was constructed by deleting a 184-bp EcoRI fragment corresponding to mouse Brcal amino acids 300-361 (Fig. 1A) and replacing it with a pgkneopA cassette in either the sense (s) or antisense (o) orientation. These two constructs were then subcloned into the p2TK vector to produce two final targeting vectors designated as Brcal-ko(s) and Brcal-ko(o), respectively (Fig. 1B). Both vectors were individually transfected into ES cells, and 384 colonies doubly resistant to G418 and FIAU were isolated. DNA from these colonies was analyzed by Southern blotting to identify clones containing a disruption of the Brca1 gene resulting from a targeted homologous recombination event. These were identified by the appearance of a novel HindIII fragment of the predicted size using a fragment of Brca1 genomic DNA lying $3^{\prime}$ external to the targeting vector as a hybridization probe (Figs. 1C and 2A). The use of Brcal$\mathrm{ko}(\mathrm{s})$ and Brcal-ko(o) vectors resulted in a total of 6 and 13 homologous recombinant clones, respectively. Brcalkolo) \#3 and Brcal-ko(s) \#291 were analyzed further by Southern blot analysis using different probes to confirm the targeted gene disruption (Fig. 2B).

\section{Production of Brca1 heterozygote mutants by germ-line transmission}

ES cells from clone Brcal-ko(o) \#3 and Brcal-ko(s) \#291 were injected independently into C57BL/6J blastocysts, which were then implanted into the uteri of pseudopregnant CBA female foster mice. We generated 5 germ-line chimeras from a total of 16 male chimeras, all derived from clone Brcal-ko(o) \#3. Of the 120 offspring from male chimera/female C57BL/6J crosses, $53 \%$ were heterozygous $($ Brca1 $+1-)$ and $47 \%$ homozygous wild type (Brca $1+/+)$, as shown by PCR analysis of toe DNA samples. The heterozygous mice were further confirmed by Southern blot analysis of tail DNA samples (data not shown). Heterozygous animals appear normal, healthy, and are fertile for at least 10 months after birth.

\section{Absence of wild-type Brca1 alleles leads to embryonic lethality}

To investigate the in vivo effect of the homozygous mutations, Brca1 $|+|-\mid$ mice were interbred. The genotypes of offspring were determined at 1 week of age by PCR
Figure 1. Strategy for the generation of a targeted mutation in the mouse Brcal gene. $(A)$ Restriction map of the mouse Brca1 fragment, encompassing exon 11 and flanking DNA. An 8.0-kb HindIII-BamHI fragment was used to create the replacement targeting vector. $(B)$ Restriction map of the targeting constructs Brcal-ko(s) and Brcal-ko(o). A 184-bp EcoRI fragment from the 5 ' end of exon 11 was deleted and replaced with a $p g k n e o p A$ cassette in the sense and antisense orientation with re spect to the Brcal gene. In addition, the genomic fragment was flanked by two pMCl-tk cassettes. $|C|$ The predicted structure of a mutant allele after homologous recombination. The probes used for identification of allele-specific recombination are also shown. (D) The expected sizes of various restriction fragments detected by flanking and neo probes. Abbreviations: (RI) EcoRI; (RV) EcoRV; (B) BamHI; (H) HindIII, (S) SalI; (X) XhoI.

\footnotetext{
A

D
}
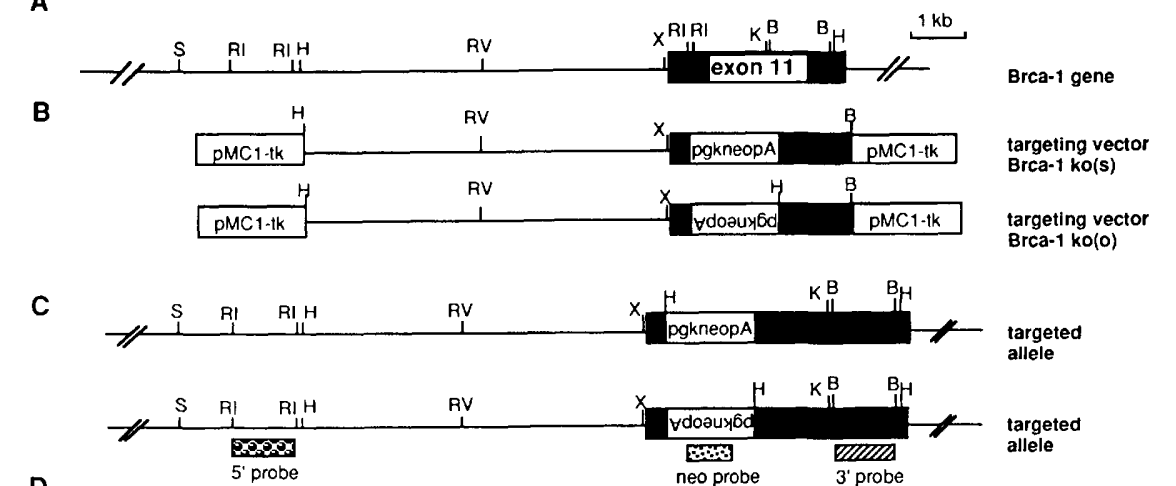

Expected Restriction Fragments

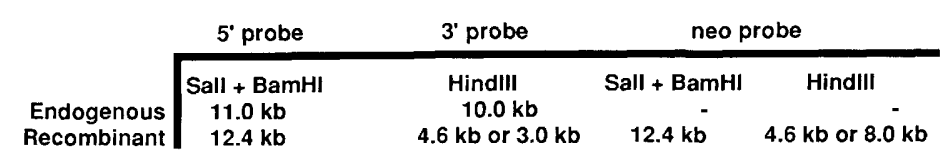


A

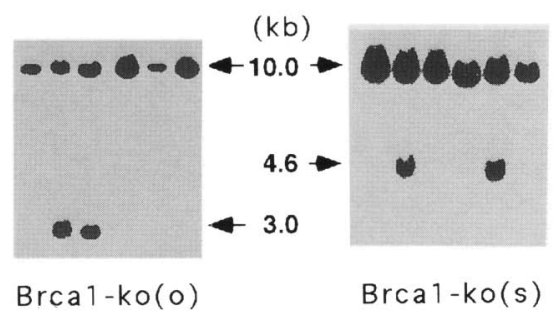

B
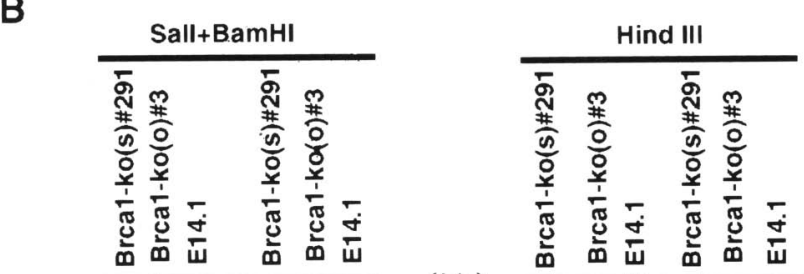

probe:
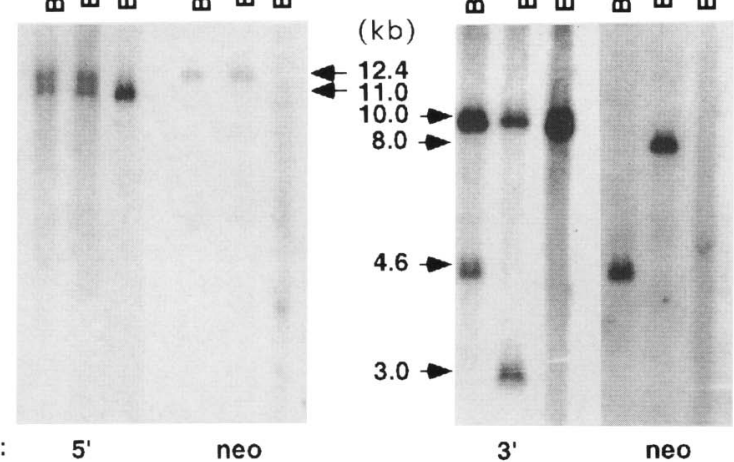

Figure 2. Targeted disruption of the Brca1 gene in mouse ES cells. (A) Initial screen of the targeted Brca1 clones by Southern blotting analysis. The HindIII 4.6- or $3.0-\mathrm{kb}$ restriction fragment indicated the expected recombinant allele by Brcal-ko(s) or Brcal-kolo) vectors, respectively. $(B)$ Confirmation of the targeted disruption. DNA samples from parental E14.1 cells and two candidate recombinant clones [Brcal-kolo) 3 and Brcalko(s) 291] were digested with HindIII or Sall-BamHI and probed with either of the flanking probes or the neo probe. An additional fragment of the expected size was found in each of the recombinant clones.

analysis of toe DNA samples. Of the 97 animals tested, $63 \%$ were heterozygous and $37 \%$ were wild type. No mice homozygous for the mutation were detected, indicating that the Brca1 $|-/-|$ mutants died in utero (Table 1). To determine the time of death, pregnant females from $B r c a 1|+|-\mid$ intercrosses were sacrificed, and the fetuses at different gestation times from E8.5 to E12.5 were examined. Of the 81 decidua tested, $58(72 \%)$ contained morphologically normal fetuses, of which 39 $(48 \%)$ were heterozygous, $19(24 \%)$ were wild type, and none were homozygous. The remaining $23(28 \%)$ decidua were much smaller and contained completely resorbed embryos (Table 1; Fig. 3J,O), indicating that the Brca1 $-/-$ ) mutant concepti die before E8.5.

\section{Developmental deficiency in Brcal(-/ -) mutant} embryos appears shortly after postimplantation

To precisely pinpoint the differences between wild-type and Brca1 $-/-\mid$ mutant embryos, we next examined the histology of embryos between implantation and gastrulation. Intact decidual swellings of litters from Brca1 + I -) intercrosses obtained between E4.5 and E7.5 (Table 1) were fixed, sectioned, and stained with hematoxylin/ eosin. Following implantation (E4.5-E5.5), abnormalities that distinguished normal concepti from Brca1|-I -) concepti could be readily observed. Both wild-type (Fig. 3A,B) and heterozygous embryos (data not shown) show normal growth and elongation of the egg cylinder, which contains both embryonic and extraembryonic ectoderm and distinct proamniotic cavities. In striking contrast, Brca1 $\mid-1-1$ embryos are at least $50 \%$ smaller than the wild type and fail to form egg cylinders (Fig. $3 \mathrm{~F}, \mathrm{G}, \mathrm{K}, \mathrm{L})$, although they do display embryonic and extraembryonic tissues at this stage (Fig. 3G,L). By E6.5, wild-type embryos are almost ready for gastrulation, with the egg cylinders nearly filling the yolk sac cavities. Elongated proamniotic and distinct exocoelomic cavities are also well developed (Fig. 3C). By comparison, Brca1(-/ - ) embryos show increasing cellular disorganization and start to degenerate (Fig. $3 \mathrm{H}, \mathrm{M})$. By the time wild-type embryos undergo gastrulation (E7.5) and the mesoderm develops (Fig. 3D), the Brca1 (-/ -) embryos are significantly developmentally retarded and there is no sign of mesoderm differentiation (Fig. 3I,N). Of the 26 decidua examined at E8.5, $8(30 \%)$ contained no embryo, indicating complete resorption (Table 1; Fig. 3J,O).

Table 1. Genotype analysis of the progeny from Brcal $|+/-|$ heterozygous intercrosses

\begin{tabular}{|c|c|c|c|c|c|c|}
\hline \multirow[b]{2}{*}{ Age (DNA source) } & \multirow[b]{2}{*}{ Litter } & \multirow[b]{2}{*}{ Number } & \multicolumn{3}{|c|}{ Genotype } & \multirow[b]{2}{*}{ Resorbed } \\
\hline & & & $+1+$ & $+1-$ & $-1-$ & \\
\hline 10 days (toes) & 19 & 97 & 36 & 61 & 0 & \\
\hline E9.5-12.5 (yolk sac) & 7 & 55 & 11 & 29 & 0 & 15 \\
\hline E8.5 (yolk sac) & 1 & 9 & 3 & 5 & 0 & 1 \\
\hline E8.5 (paraffin sections) & 2 & 17 & 5 & 5 & 0 & 7 \\
\hline E7.5 (paraffin sections) & 3 & 23 & 6 & 14 & 3 & \\
\hline E6.5 (paraffin sections) & 5 & 37 & 10 & 20 & 7 & \\
\hline E5.5 (paraffin sections) & 3 & 21 & 10 & 6 & 5 & \\
\hline E4.5 (paraffin sections) & 1 & 7 & 3 & 2 & 2 & \\
\hline E3.5 (outgrowth) & 6 & 37 & 10 & 19 & 8 & \\
\hline
\end{tabular}


Figure 3. Histological sections of wildtype and Brca1 $\mid-/-1$ mutant embryos grown in utero. The uteri of Brca1 $+1-1$ females were dissected between 4.5 and 8.5 days after intercross matings, and $4-\mu \mathrm{m} \mathrm{sec}$ tions were prepared as described in Materials and methods. All uterine decidua were sectioned transversely according to the nomenclature of Smith (1985), and the mesometrial to anti-mesometrial axis is left to right. $(A-E)$ Wild-type embryos; $(F-O)$ Brca1 - / - ) embryos; $(A, F, K)$ E4.5 egg cylinders; $(B, G, L)$ E5.5 egg cylinders; $(C, H, M)$ E6.5 embryos; $(D, I, N)$ E7.5 embryos; $(E, I, O)$ E8.5 embryos. Note the appearance of the proamniotic cavity and the clearly differentiated embryonic and extraembryonic ectoderm in a wild-type E4.5 egg cylinder $(A)$, an elongated egg cylinder ready for gastrulation in E6.5 embryo $(C)$, and a gastrulating embryo with primitive streak and mesoderm differentiation in an E7.5 embryo $(D)$. Abbreviations: (eee) Extra-embryonic ectoderm; (pac) proamniotic cavity; (al) allantois; (am) amnion; (ch) chorion; (ec) exocoelomic cavity; (ee) embryonic ectoderm; (em) embryo mass; (hf) head fold; (ht) heart; (ne) neuroepithelium; (pe) parietal endoderm; (ve) viceral endoderm. (Insets in $F$ and $K$ ) enlarged twofold. Bar, $100 \mu \mathrm{m}$.

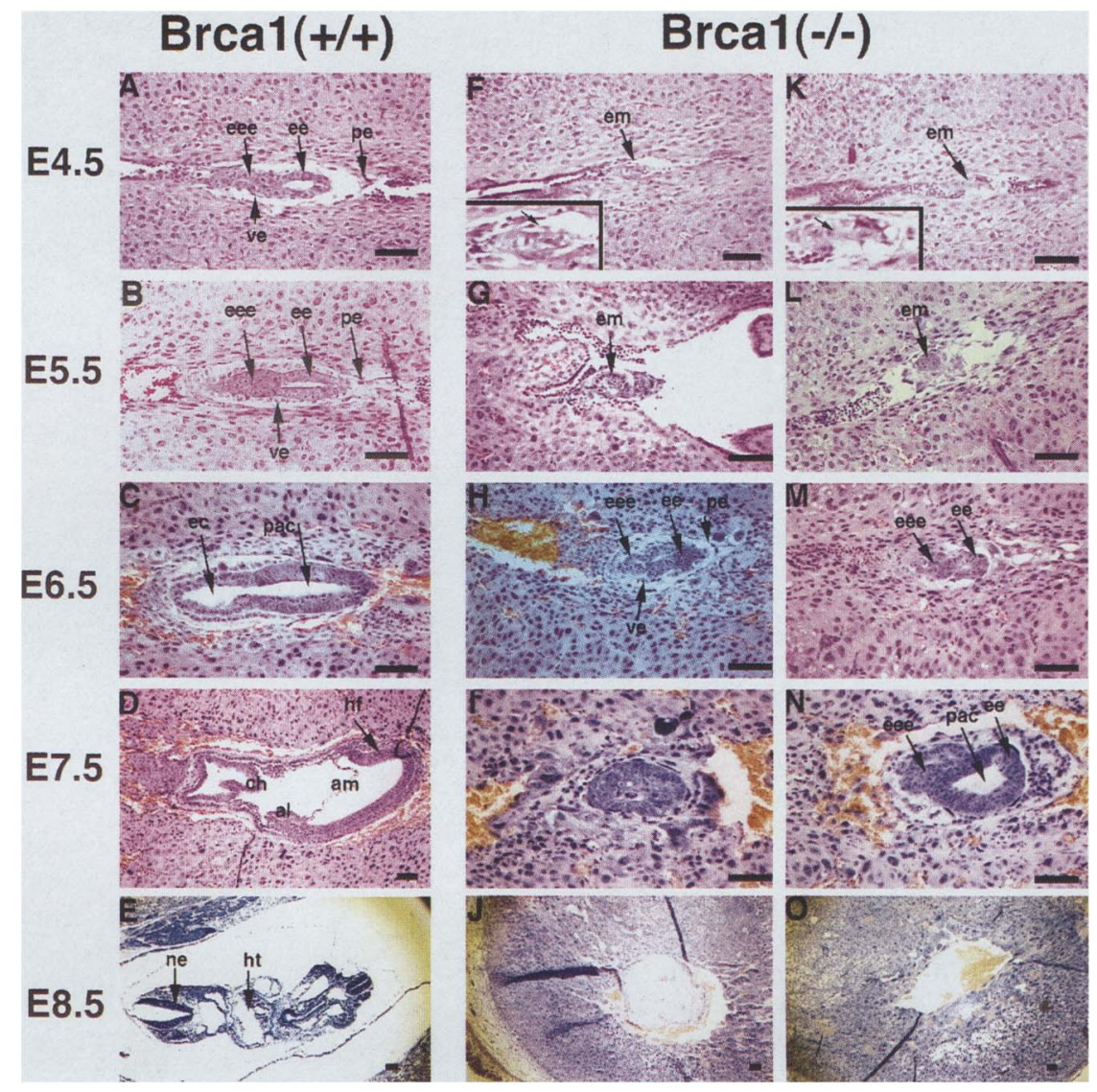

The morphologically abnormal phenotype is inferred to be the consequence of the homozygous mutant genotype. To confirm that the smaller malformed embryos do result from the loss of the wild-type Brca1 gene, sectioned embryonic tissues are collected by microdissection and subjected to PCR genotyping analysis. PCR analysis of E4.5 littermates representative of Brca1 heterozygote matings shows that the developmentally impaired embryos are homozygous for the mutated Brca1 allele (Fig. 4A, right, and B). These observations demonstrate that Brca1 $(-/-)$ embryos have growth and morphogenetic defects before the onset of gastrulation and die before E8.5. To test whether the Brca1|-/ $\mid$ | embryos between E5.5 and E6.5 remain alive, we injected 5-bromo-2'-deoxyuridine (BrdU) $(100 \mu \mathrm{g} / \mathrm{gram}$ body weight) intraperitoneally into heterozygous pregnant females $1 \mathrm{hr}$ before sacrifice. The embryos were fixed, sectioned, and subjected to immunostaining with anti-BrdU antibody. The Brca1 $(-/-)$ embryos were found to incorporate $\mathrm{BrdU}$, indicating that the mutant embryos synthesize DNA (Fig. 5C,D). These results suggest that the cells are still alive, although the embryos are underdeveloped. When we compared the percentage of BrdU-labeled cells of three genotypes $(+1+,+1-$, and $-1-1$ at E5.5-E6.5 (Fig. 5E), the wild-type and heterozygote embryos had $\sim 82 \%-85 \%$ of their nuclei labeled, whereas the homozygous mutant embryos had only $61 \%-63 \%$. On the other hand, when we compared apoptotic index obtained by TUNEL [terminal deoxynucleotide transferase TdT)-mediated dUTP-biotin nick end labeling] assays of wild-type and mutant embryos, no significant difference was found (data not shown). These results indicate that the overall growth and morphogenetic defect in the Brca1 $(-/-)$ mutant embryos are, at least in part, attributable to a decrease in the proliferation capability, not an increase in apoptosis of embryonic cells.

\section{Brcal(-/-) blastocysts have a growth disadvantage in culture}

Blastocyst outgrowth in an in vitro culture offers an alternative method to study early postimplantational development. Blastocysts (E3.5) from intercrosses between Brca1 $+|-|$ mice were isolated by uterine flushing, and photographed individually before and after in vitro culture. All 37 blastocysts examined were indistinguishable (Fig. 6A,C,E,H), indicating that embryos homozygous for the targeted mutation of Brca1 were morphologically normal before implantation. However, a disadvantage in the outgrowth of homozygous embryos was noted after 5 days in culture. Whereas cultured blastocysts of each genotype $(+1+,+1-$, and $-1-)$ gave rise to adherent sheets of trophoblastic giant cells, the Brca1 $-/-\mid$ blastocysts showed impaired outgrowth of the inner cell mass (Fig. 6F, G,I,J). These results are consistent with the 


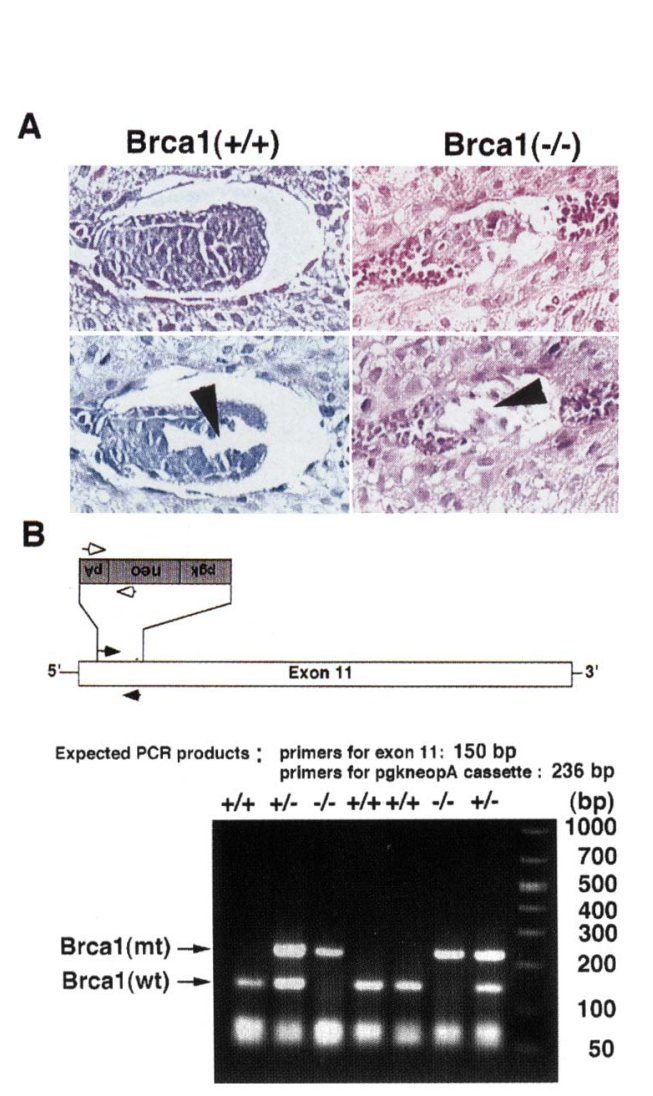

Figure 4. MD-PCR genotype analysis of littermate E4.5 embryos from a Brca1 heterozygote intercross. (A) Representative images before (top) and after (bottom) microdissection. Arrowheads point to the area from which the embryo's cells had been dissected out for DNA isolation and PCR analysis. $(B)$ Design of primers for detection of exon 11 in the wild-type Brca1 gene (solid arrow), and those for the pgkneopA cassette (open arrow) integrated into mouse genome by homologous recombination. PCR products amplified from the DNA of microdissected embryonic samples were resolved on a $4 \%$ NuSieve/SeaKem $(3: 1)$ agarose gel in TAE buffer. Abbreviations: (pgk) phosphoglycerate kinase I promoter; (neo) gene for neomycin resistance; $(\mathrm{pA})$ polyadenylation sequence of the bovine growth hormone gene.

in vivo observations of growth retardation in homozygous embryos as described above.

\section{Discussion}

In humans, mutations of the $B R C A 1$ gene are strongly implicated in familial breast, ovarian, and perhaps other types of cancer. One of the purposes in generating Brca1 mutant mice was to establish an in vivo model system to study the genetic and/or environmental factors responsible for the pathogenesis of these cancers. In concert with Knudson's "two-hit" theory of carcinogenesis (Knudson 1971), germ-line mutation of one allele of the $B R C A 1$ gene followed by loss of the other allele in somatic cells is currently a favored explanation for familial breast and ovarian tumorigenesis. If human $B R C A 1$ and mouse Brca1 are functionally equivalent, Brca1 $|+|-\mid$ mice should produce breast, ovarian, and/or other type of cancers. Consistent with the results published previ-
Targeted mutation of the murine Brca1

A

B

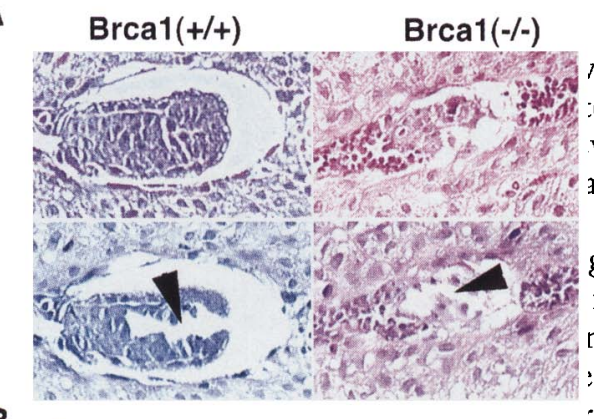

$\rightarrow$

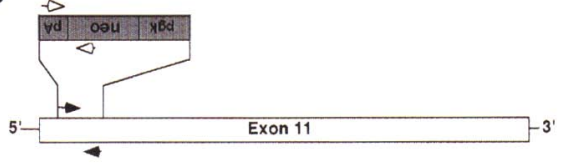

Expected PCR products: primers for exon 11: $150 \mathrm{bp}$ mentally and in huprimers for pgkneopA cassette : 236 bp arate functions im-

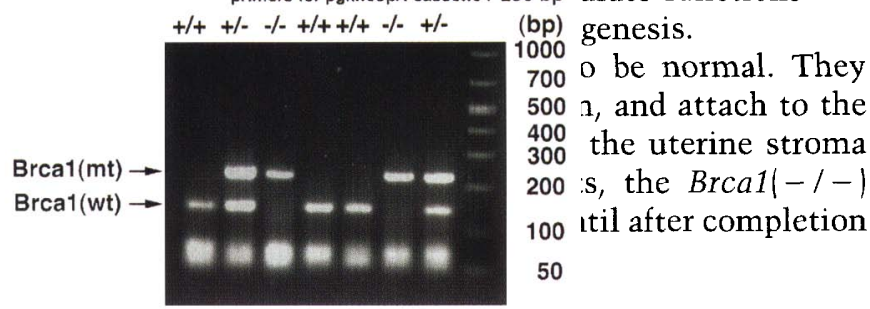

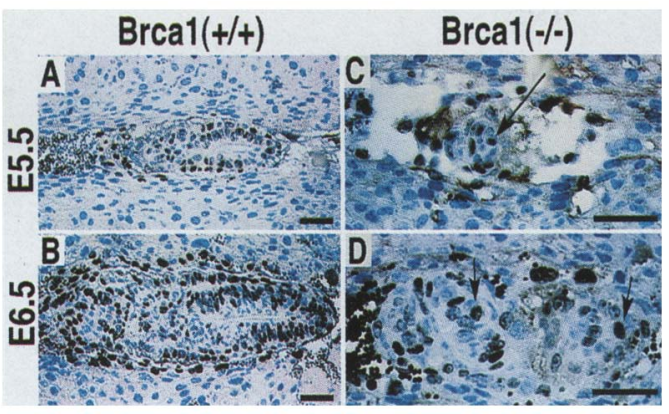

E

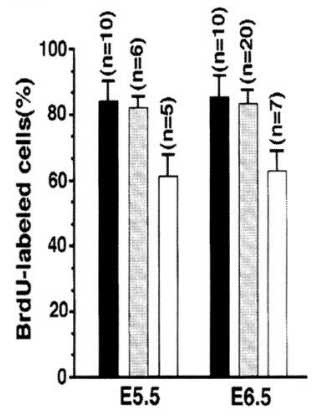

Figure 5. Epiblast cells proliferation is retarded in Brca1 $-/-1$ mutant embryos. In vivo BrdU incorporation was described in Materials and methods. $(A-D)$ Transverse sections of uterine decidua were immunostained with an anti-BrdU monoclonal antibody. $(A, B)$ Wild-type embryos; $(C, D)$ Brca1 -1 - $\mid$ embryos; $(A, C)$ E5.5 egg cylinders; $(B, D)$ E6.5 egg cylinders. Arrows point to BrdU-labeled cells (dark brown). Unlabeled nuclei appear blue as a result of counterstaining with hematoxylin. $(E)$ Histogram summary of the percentage of BrdU-labeled cells of different genotypes. (Solid bar) Brca1 $1+1+$ ); (shaded bar) Brca1) +1 - ); (open bar)Brca1 $(-/-)$. Numbers in parenthesis indicate the number of embryos analyzed. Two-tailed $P$ value (homozygote mutant vs. wild-type/heterozygote) is $<0.0001$. Bar, $50 \mu \mathrm{m}$. 

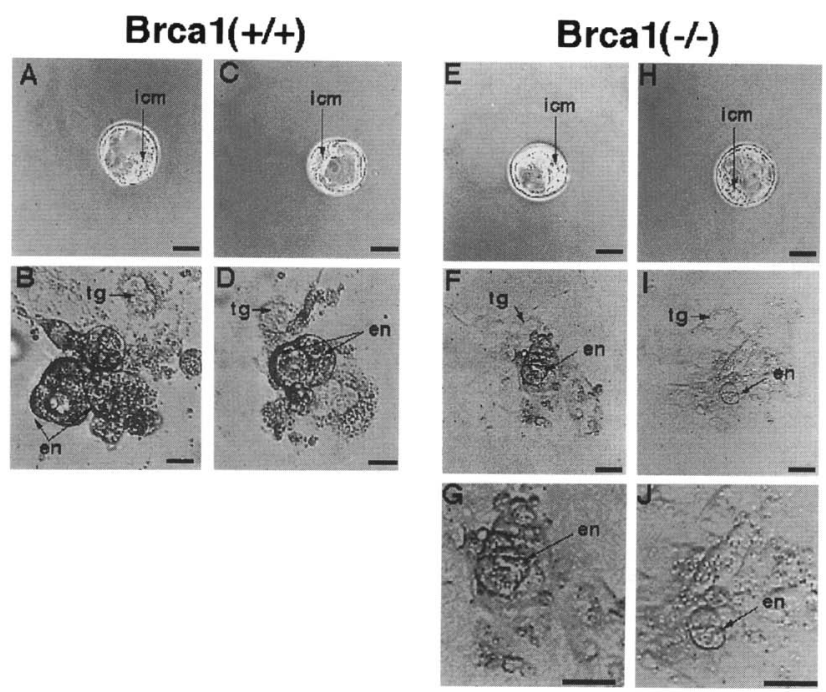

Figure 6. Outgrowths of wild-type and Brca1 $-1-\mid$ blastocysts in vitro. Wild-type blastocysts $(A, C)$ and Brca1 $1-/-\mid$ blastocysts $(E, H)$ appear to be morphologically normal (arrows point to inner cell mass). Representative example of wild-type $(B, D)$ and Brca1 $|-/-|\langle F, I\rangle$ blastocysts cultured for 5 days in vitro. $G$ and $J$ are higher magnifications of $F$ and $I$, respectively. Abbreviations: (en) endoderm; (icm) inner cell mass; (tg) trophoblast giant cells. Bar, $10 \mu \mathrm{m}$.

of these steps in implantation. After implantation (E4.5), but before gastrulation (E7.5), the inner cell mass of wildtype embryos undergoes rapid proliferation that extends into the blastocoel cavity to form a structure known as the egg cylinder (Fig. 3A-C). The egg cylinder is initially a double-layered structure that encloses a narrow lumen termed the proamniotic cavity. The two layers consist of an inner layer of ectoderm and an outer layer of endoderm cells (Kaufman 1992). In Brca1 (-/ - / mutant embryos, the embryonic and extraembryonic tissues are present but are severely retarded in growth. Although the cells remain alive, the embryos are incapable of proceeding toward gastrulation (Fig. 3F-I,K-N). By E8.5, the Brca1 $(-/-)$ concepti are resorbed completely. Because maternal RNAs are typically degraded (Sawicki et al. 1981) and at least some embryonic de novo gene expression is required (Johnson 1981) after implantation, it is not clear whether maternal Brcal can maintain the cell viability until E7.5. Consistent with in vivo observations, the in vitro blastocyst outgrow th experiments also showed a disadvantage in the growth of the Brca1 $1-1-1$ inner cell mass (Fig. 6), suggesting that the Brca1 is important for cell growth at this early embryonic stage.

The phenotype of Brca1|-/-| embryos described here is similar to those of other mutant mice. The murine evx1|-/-) mutant leads to embryonic malformations after implantation but before gastrulation (Spyropoulos and Capecchi 1994). Unlike Brca1/-/-) mutants, evx $1(-/-\mid$ mutants failed to differentiate into distinct embryonic and extraembryonic tissues. Cells in evx $11-1$ -) embryos do not establish proper communication between embryonic and extraembryonic tissues, which is critical for their further differentiation. The $f g f r-1 \mid-/-1$ mouse mutant is also similar in terms of the timing of embryonic demise. Unlike Brca1 - / - | mutants, however, $f g f r-1|-/-|$ concepti do form egg cylinders, undergo gastrulation, and generate mesoderm. In this instance, embryonic lethality may be caused by the aberrant mesodermal patterning (Deng et al. 1994; Yamaguchi et al. 1994). The embryos of the fug1 (failure to undergo gastrulation) mouse mutant seem to be the closest to the Brca1 $-1-\mid$ homozygotes with regard to timing and the high degree of disorganization within the embryo. Homozygous fug1 mutant embryos also arrest growth at the egg cylinder stage (E6.0) and are mostly resorbed by E8.5 (DeGregori et al. 1994). Little is known about the genes required for the differentiation of primitive ectoderm and endoderm, the formation of the proamniotic cavity, or the organization of the ectoderm into an organized epithelium. The genetic evidence from our results demonstrated that like fug1, Brca1 may be required for the organized development of the embryo at the egg cylinder stage, or for subsequent gastrulation. Whether Brca1 interacts with fug1 or other cellular factors in the control of early morphogenesis is unknown.

The developmental stage of embryonic death of the Brca1 $|-/-|$ mutant in our experiments was different from that published by Gowen et al. (1996). In their report, mice lacking a functional Brca1 gene exhibited neural tube defects at E9.5. These neural defects were proposed to be the major cause of embryonic lethality between E10 and E13, which is later than what we observed here. To confirm that the mutant phenotype was concurrent with loss of the wild-type Brca1 gene, we genotyped all sectioned decidua by MD-PCR and obtained a complete correlation between the mutant genotype and the phenotype. Although the discrepancy between these two observations remains to be resolved, the phenotypic variation of the two Brca1 mutations is probably not attributable to different genetic backgrounds because both mutations were analyzed on the hybrid $129 /$ C57BL backgrounds.

Interestingly, the phenotypes of three MRF4 homozygous mutants varied from perinatal death to viable with only minor abnormalities (Braun and Arnold 1995; Patapoutian et al. 1995; Zhang et al. 1995). One potential explanation for these phenotypic variations is that the regulation of a neighboring gene, named Myf5, was interfered with by two of the constructs but not by the other (Olson et al. 1996). In our targeting construct, a 184-bp EcoRI fragment within the 5' end of exon 11 was deleted and replaced with the pgkneopA cassette. In their construct, Gowen et al. (1996) deleted a 1.7-kb XhoI-KpnI genomic fragment that contains $0.1 \mathrm{~kb}$ of intron 10 in addition to $1.6 \mathrm{~kb}$ of exon 11. Although we do not know whether either of the insertion/deletion manipulations of Brca1 affects the expression of other genes surrounding exon 11 of Brca1, removal of a splicing acceptor site in the latter construct may generate different splicing variants of Brca1. Nevertheless, the evidence together strongly supports the notion that Brcal is needed for mouse early embryonic development. 
Recently, we isolated two Brcal-interacting proteins that are structurally similar to transcription factors. One is a LIM-type homeo box-containing protein and the other is a zinc-finger motif-containing protein $/ \mathrm{S}$. Li and W.-H. Lee, unpubl.). Both classes of proteins are known to participate in the control of development. Our hypothesis is that Brcal, at least in the mouse, somehow participates in regulating the spatial-temporal organization of the developing embryo through interactions with these, and perhaps other, developmental control proteins. This exciting possibility is currently under investigation.

\section{Materials and methods}

\section{Construction of targeting vectors}

The mouse Brcal gene was isolated by screening a $\lambda \mathrm{DASH}$ mouse genomic library derived from the $129 / \mathrm{Sv}$ mouse strain (provided by Dr. Tom Doetschman, University of Cincinnati, $\mathrm{OH}$ ), using a 3.5 -kb fragment of human $B R C A 1$ exon 11 as a probe. Positive clones were subcloned into the pBluescript SK vector (Stratagene). Restriction mapping and DNA sequencing of the intron 10-exon 11 junction yielded the restriction map shown in Figure 1A. To generate a targeting vector, an $8.0-\mathrm{kb}$ HindIII-BamHI fragment of the mouse Brca1 gene containing exon 11 was subcloned into the pBluescript SK vector (Stratagene), yielding the plasmid pHB-8. The HindIII site was then opened and changed to BamHI by ligation with a BamHI linker. A 184-bp EcoRI fragment, corresponding to amino acid residues 300-361, was deleted and replaced with a pgkneopA cassette (Soriano et al. 1991) in both the sense and antisense orientation [designated as Brcal-neo(s) and Brcal-neo(o), respectively]. These two constructs were then subcloned into the $\mathrm{p} 2 \mathrm{TK}$ vector (Lee et al. 1992) to produce two final targeting vectors designated as Brcal-ko(s) and Brcal-ko(o), respectively.

\section{Electroporation and selection of ES cells}

E14.1 ES (Handyside et al. 1989) cells derived from mouse strain $129 /$ Ola were maintained on a monolayer of mitomycin C-inactivated, neomycin-resistant, fibroblast feeder cells, as described previously (Robertson 1987). Thirty micrograms of SalIlinearized targeting vector was electroporated into a suspension of trypsinized cells $\left(7 \times 10^{6}\right)$ in Dulbecco's modified Eagle medium (DMEM) (GIBCO/BRL) using a Bio-Rad gene pulser (250 $\mu \mathrm{F}, 800 \mathrm{~V}$ ). Cells were then incubated at room temperature for $5 \mathrm{~min}$, plated, and allowed to recover for $24 \mathrm{hr}$ before selection in medium containing G418 $(250 \mu \mathrm{g} / \mathrm{ml})$ and FIAU $(1 \mu \mathrm{M})$. Cells were fed daily, and after 8 days the resulting double-resistant ES clones were individually picked and transferred onto 24-well plates with feeders. On the following day, each clone was trypsinized and divided in half. One half was frozen $\left(-80^{\circ} \mathrm{C}\right)$, whereas the other half was plated into a 12 -well plate without feeder cells and used to prepare DNA.

\section{Analysis of targeted ES cell clones}

The analysis of DNA from ES cell clones was described previously (Laird et al. 1991). In brief, cells in a 12-well plate were washed with PBS, lysed in $0.5 \mathrm{ml}$ of lysis buffer containing 50 $\mathrm{mm}$ Tris- $\mathrm{HCl}$ (pH 7.5), $100 \mathrm{~mm} \mathrm{NaCl}, 10 \mathrm{~mm}$ EDTA, $0.5 \%$ SDS, and $0.1 \mathrm{mg} / \mathrm{ml}$ of proteinase $\mathrm{K}$, and transferred into a $1.5-\mathrm{ml}$ Eppendorf tube. After $5 \mathrm{hr}$ of incubation at $55^{\circ} \mathrm{C}$ with shaking, an equal volume of isopropanol was added, and DNA was al- lowed to precipitate by gentle inversion of the tube several times. The supernatant was discarded, and the DNA was washed with $70 \%$ ethanol, air-dried, and resuspended in distilled water. DNA $(15 \mu \mathrm{g})$ was digested in $30 \mu \mathrm{l}$ of a restriction enzyme mixture $(1 \times$ restriction buffer, $100 \mathrm{mg} / \mathrm{ml}$ of bovine serum albumin (BSA), $50 \mu \mathrm{g} / \mathrm{ml}$ of RNaseA, and 15 units of HindIII) overnight at $37^{\circ} \mathrm{C}$. Electrophoresis and Southern blotting of the digested DNA was performed as described previously (Sambrook et al. 1989). A ${ }^{32}$ P-labeled 1.1-kb BamHI fragment, which lies $3^{\prime}$ of the genomic sequence in the targeting vector, identified bands of 10.0 and $3.0 \mathrm{~kb}$, or 10.0 and $4.6 \mathrm{~kb}$, corresponding to germ-line wild-type Brca1 and homologous recombinant bands. Targeted clones were recovered from the 24-well plates and expanded in 6-well plates. DNA from these clones was then digested with BamHI and SalI and probed with a 5' flanking probe. In addition, a neo probe was used to confirm that only homologous recombination had occurred in targeted clones rather than a random integration event.

\section{Generation of mice carrying the disrupted Brcal allele}

Two different targeted ES clones, Brcal-ko(o) 3 and Brcal-ko(s) 291 , were used to generate chimeric mice according to procedures described previously (Bradley 1987). C57BL/6J blastocysts injected with 10-12 ES cells were implanted into pseudopregnant $\mathrm{F}_{1}(\mathrm{CBA} \times \mathrm{C} 57 \mathrm{BL} / 6)$ foster mothers (The Jackson Laboratory, Bar Harbor, ME). Chimeric mice, identified by agouti coat color, were mated with C57BL/6J mice. Offspring with agouti coat color were tested for the presence of the targeted locus by PCR and Southern blotting analysis. Heterozygotes were interbred, and PCR analysis was used to distinguish between offspring with zero, one, or two copies of the mutant gene.

DNA isolation, PCR genotyping, and histology of embryos from Brcal $+1-$ intercrosses

$F_{1}$ mice heterozygous for the Brca1 mutant allele were mated, and toes were cut from the $F_{2}$ progeny for genotyping analysis. For timed pregnancies, the day on which a vaginal plug was detected was considered to be E0.5. At desired time points, the embryos were dissected from maternal decidua for further analysis. For embryos older than E8.5, the visceral yolk sac was collected and subjected to genotype determination by PCR. DNA from toes, yolk sacs, and blastocysts was prepared and analyzed by PCR as follows. Tissues were lysed at $55^{\circ} \mathrm{C}$ in $40 \mu \mathrm{l}$ of lysis buffer [10 mM Tris- $\mathrm{HCl}(\mathrm{pH} 8.3), 50 \mathrm{mM} \mathrm{KCl}, 2.5 \mathrm{mM}$ $\mathrm{MgCl}_{2}, 0.1 \mathrm{mg} / \mathrm{ml}$ of gelatin, $0.45 \% \mathrm{NP}-40,0.45 \%$ Tween 20 , and $60 \mu \mathrm{g} / \mathrm{ml}$ of proteinase $\mathrm{K}]$ for $1 \mathrm{hr}$. Samples were then boiled for $10 \mathrm{~min}$ and cooled on ice. Seven microliters of proteinase $\mathrm{K}$-digested cell lysate was mixed with $18 \mu \mathrm{l}$ of PCR cocktail solution containing $50 \mathrm{~mm} \mathrm{KCl}, 1.5 \mathrm{~mm} \mathrm{MgCl}, 10 \mathrm{~mm}$ Tris- $\mathrm{HCl}$ $(\mathrm{pH} 8.3), 0.001 \%$ gelatin, $200 \mu \mathrm{M}$ each of the four dNTPs, $0.4 \mu \mathrm{M}$ of each primer, and 0.5 unit of recombinant Taq polymerase (AmpliTaq; Perkin-Elmer). The mixture was then overlaid with $20 \mu \mathrm{l}$ of light mineral oil. PCR was performed for 35 cycles using a pTC-100 thermal controller (MJ Research, Inc.) using the following reaction conditions: Denaturing temperature of $94^{\circ} \mathrm{C}$ for $30 \mathrm{sec}_{\text {; }}$ annealing temperature of $65^{\circ} \mathrm{C}$ for $1 \mathrm{~min}$; and elongation temperature of $72^{\circ} \mathrm{C}$ for $1 \mathrm{~min}$. The resulting PCR products were resolved on $4 \% \mathrm{NuSieve/SeaKem}(3: 1$; FMC) composite gel in TAE buffer at $80 \mathrm{~V}$ for $30 \mathrm{~min}$ and visualized with UV light after staining with ethidium bromide. For the targeted allele, a 236bp product was generated using a sense oligonucleotide, $5^{\prime}$ TGATATTGCTGAAGAGCTTGGCGGC-3' and an antisense oligonucleotide, 5'-TGGGAGTGGCACCTTCCAGGGTCAA$3^{\prime}$, within the pgkneopA cassette. To detect the wild-type allele, 
a 150-bp product was generated using a sense oligonucleotide, 5'-AACAGCCTGGCATAGCAGTGAGCCA-3', and antisense oligonucleotide, 5'-TTGCGGGTGAGTCCACTTCTCTCTA3' within exon 11 of Brca1. For embryos between E4.5 and E7.5, entire uteri were fixed in $4 \%$ paraformaldehyde overnight at $4^{\circ} \mathrm{C}$. Uterine horns were excised and dehydrated through a graded ethanol series, cleared in chloroform, and then infiltrated and embedded in Paraplast X-tra (Polysciences). Sections (4 $\mu \mathrm{m})$ were collected on Superfrost/Plus microscope slides (Fisher Scientific), stained with Mayer's hematoxylin/eosin, and mounted in Canada Balsam (Fisher Scientific). Images were recorded using a C5810 Color Camera (Hamamatsu) and cropped using a Macintosh Power PC and Adobe Photoshop Software. The slides with sections were demounted in xylene followed by soaking in 100\% ethanol and air-dried. Embryonic tissues were microdissected and collected into glass capillaries $(\sim 50 \mu \mathrm{m}$ diam.) mounted on a micromanipulator (Leitz), under 400-fold magnification, and transferred into a 0.5- $\mathrm{ml}$ Eppendorf tube containing $7 \mu \mathrm{l}$ of lysis buffer under $20 \mu \mathrm{l}$ of light mineral oil. Cells were lysed at $55^{\circ} \mathrm{C}$ for $1 \mathrm{hr}$. The proteinase $\mathrm{K}$ was then inactivated by incubation at $95^{\circ} \mathrm{C}$ for $10 \mathrm{~min}$, and the mixture was then cooled on ice. The PCR cocktail solution $(18 \mu l)$ was then added into the tube and mixed with the DNA sample by centrifugation at $12,000 \mathrm{rpm}$ for $1 \mathrm{~min}$. PCR was performed for 50 cycles.

\section{In vitro blastocyst culture}

Blastocyst cultures followed those described previously (Hsu 1979), with some modifications. Briefly, blastocysts were isolated from females at E3.5 and cultured for 5 days on tissue culture plates in DMEM plus $20 \%$ fetal bovine serum, supplemented with BSA ( $4 \mathrm{mg} / \mathrm{ml})$, glutamine, antibiotics, and 2 -mercaptoethanol $(0.1 \mathrm{mM})$. Blastocyst outgrowths were inspected daily and photographed to monitor their development. Finally, they were lysed and genotyped by PCR.

\section{Detection of BrdU incorporation by immunohistochemistry}

At the desired time points, BrdU (100 $\mu \mathrm{g} / \mathrm{gram}$ body weight) (Sigma) was injected intraperitoneally into pregnant females. One hour later, the entire uterus was dissected and fixed in $4 \%$ paraformaldehyde overnight at $4^{\circ} \mathrm{C}$. The individual decidua were embedded, sectioned, and subjected to further analysis. Immunohistochemical detection of BrdU incorporation was performed as described previously (Lee et al. 1994). The percentage of cells incorporating BrdU in each embryo was determined by counting $>50$ cells in representative histological sections. Statistical comparisons were performed by two-tailed ANOVA using In Stat software (Graph Pad, San Diego, CA)

\section{Acknowledgments}

We thank Drs. Alexander Yu Nikitin for his critical technical guidance; David Sharp, Andrew Farmer, and Daniel J. Riley for their critical comments; and Phang-Lang Chen and Chi-Fen Chen for their contribution on the initial work of this project. This work was supported in part by National Cancer Institute grants CA58318 and P50-CA58183 Specialized Program of Research Excellence in Breast Cancer (SPORE).

The publication costs of this article were defrayed in part by payment of page charges. This article must therefore be hereby marked "advertisement" in accordance with 18 USC section 1734 solely to indicate this fact.

\section{References}

Anderson, D.E. and M.D. Badzioch. 1993. Familial breast cancer risks: Effects of prostate and other cancers. Cancer 72: 114 119.

Boyd, M., F. Harris, R. Mcfariane, H.R. Davidson, and D.M. Black. 1995. A human BRCA1 gene knockout. Nature 375: 541-542.

Braun, T. and H.-H. Arnold. 1995. Inactivation of Myf-6 and Myf-5 genes in mice leads to alternations in skeletal muscle development. EMBO J. 14: 1176-1186.

Bradley, A. 1987. Production and analysis of chimeras. In Teratocarcinomas and embryonic stem cells: A practical approach (ed. E.J. Robertson), pp. 113-151. IRL Press, Oxford, UK.

Chen, Y., C.-F. Chen, D.J. Riley, D.C. Allred, P.-L. Chen, D. Von Hoff, C.K. Osborne, and W.-H. Lee. 1995. Aberrant subcellular localization of BRCAl in breast cancer. Science 270: 789-791.

Chen, Y., A.A. Farmer, C.-F. Chen, D.C. Jones, P.-L. Chen, and W.-H. Lee. 1996. BRCAl is a $220 \mathrm{kDa}$ nuclear phosphoprotein that is expressed and phosphorylated in a cell cycle dependent manner. Cancer Research (in press).

DeGregori, J., A. Russ, H. von Melchner, H. Rayburn, P. Priyaranjan, N.A. Jenkins, N.G. Copeland, and H.E. Ruley. 1994. A murine homolog of the yeast RNAl gene is required for postimplantation development. Genes \& Dev. 8: 265276.

Deng, C.-X., A. Wynshaw-Boris, M.M. Shen, C. Daugherty, D.M. Ornitz, and P. Leder. 1994. Murine fgfr-1 is required for early postimplantation growth and axial organization. Genes \& Dev. 8: 3045-3057.

Futreal, P.A., Q. Liu, D. Shattuck-Eidens, C. Cochran, K. Harshman, S. Tavtigian, L.M. Bennett, A. Haugen-Strano, J. Swensen, Y. Miki, K. Eddington, M. McClure, C. Frye, J. Weaver-Feldhaus, W. Ding, Z. Gholami, P. Soderkvist, L. Terry, S. Jhanwar, A. Berchuck, J.D. Lglehart, J. Marks, D.G. Ballinger, J.C. Barrett, M.H. Skolnick, A. Kamb, and R. Wiseman. 1994. BRCAl mutations in primary breast and ovarian carcinomas. Science 266: 120-122.

Gowen, L.C., B.L. Johnson, A.M. Latour, K. Sulik, and B.H. Koller. 1996. Brcal deficiency results in early embryonic lethality characterized by neuroepithelial abnormalities. Nature Genet. 12: 191-194.

Hall, J.M., M.K. Lee, B. Newman, J.E. Morrow, L.A. Anderson, B. Huey, and M.-C. King. 1990. Linkage of early-onset breast cancer to chromosome 17q21. Science 250: 1684-1689.

Handyside, A.H., G.T. O'Neil, M. Jones, and M.L. Hooper. 1989. Use of BRL-conditioned medium in combination with feeder layers to isolate a diploid embryonal stem cell line. Wilhelm Roux's Arch. Dev. Biol. 198: 8-55.

Hsu, Y.-C. 1979. In vitro development of individually cultured whole mouse embryos from blastocyst to early somite stage. Dev. Biol. 68: 453-461.

Johnson, M.H. 1981. The molecular and cellular basis of preimplantation mouse development. Biol. Rev. 56: 463-498.

Kaufman, M.H. 1992. The atlas of mouse development. Academic Press, London, UK.

Knudson, A.G. 1971. Mutation and cancer: Statistical study of retinoblastoma. Proc. Natl. Acad. Sci. 68: 820-823.

Laird, P.W., A. Zijderveld, K. Linders, M.A. Rudnicki, R. Jaenisch, and A. Berns. 1991. Simplified mammalian DNA isolation procedure. Nucleic Acids Res. 19: 4293.

Lane, T.F., C. Deng, A. Elson, M.S. Lyu, C.A. Kozak, and P. Leder. 1995. Expression of Brca1 is associated with terminal differentiation of ectodermally and mesodermally derived 
tissues in mice. Genes \& Dev. 9: 2712-2722.

Lee, E.Y.-H.P., C.Y. Chang, N. Hu, Y.-C.J. Wang, C.-C. Lai, K. Herrup, W.-H. Lee, and A. Bradley. 1992. Mice deficient for $\mathrm{Rb}$ are nonviable and show defects in neurogenesis and haematopoiesis. Nature 359: 228-294.

Lee, E.Y.-H.P., N. Hu, S.-S.F. Yuan, L.A. Cox, A. Bradley, W.-H. Lee, and K. Herrup. 1994. Dual roles of the retinoblastoma protein in cell cycle regulation and neuron differentiation. Genes \& Dev. 8: 2008-2021.

Marquis, S.T., J.V. Rajan, A. Wynshaw-Boris, J. Xu, G.-Y. Yin, K.J. Abel, B.L. Weber, and L.A. Chodosh. 1995. The developmental pattern of Brcal expression implies a role in differentiation of the breast and other tissues. Nature Genet. 11: $17-26$

Miki, Y., J. Swensen, D. Shattuck-Eidens, P.A. Futreal, K. Harshman, S. Tavtigian, Q.Y. Liu, C. Cochran, L.M. Bennett, W. Ding, R. Bell, J. Rosenthal, C. Hussey, T. Tran, M. McClure, C. Frye, T. Hattier, R. Phelps, A. Haugenstrano, H. Katcher, K. Yakumo, Z. Gholami, D. Shaffer, S. Stone, S. Bayer, and M. H. Skolnick. 1994. A strong candidate for the breast and ovarian cancer susceptibility gene BRCA1. Science 266: 66-71.

Olson, E.N., H.-H. Arnold, P.W.J. Rigby, and B.J. Wold. 1996. Know your neighbors: Three phenotypes in null mutants of the myogenic bHLH gene MRF4. Cell 85: 1-4.

Patapoutian, A., J.K. Yoon, J.H. Miner, S. Wang, K. Stark, and B.J. Wold. 1995. Disruption of the mouse MRF4 gene identifies multiple waves of myogenesis in the myotome. Development 121: 3347-3358.

Riley, D.J., E.Y.-H.P. Lee, and W.-H. Lee. 1994. The retinoblastoma protein: More than a tumor suppressor. Annu. Rev. Cell Biol. 10: 1-29.

Robertson, E.J. 1987. Embryo-derived stem cells. In Teratocarcinomas and embryonic stem cells: A practical approach. (ed. E.J. Robertson), pp. 71-112. IRL Press, Oxford, UK.

Sambrook, J., E.F. Fritsch, and T. Maniatis. 1989. Molecular cloning: A laboratory manual, 2nd ed. Cold Spring Harbor Laboratory Press, Cold Spring Harbor, NY.

Sawicki, J.A., T. Magnuson, and C.J. Epstein. 1981. Evidence for expression of the paternal genome in the two-cell mouse embryo. Nature 294: 450-451.

Sellers, T.A., J.D. Potter, S.S. Rich, C.R. Drinkard, R.M. Bostick, L.H. Kushi, W. Zheng, and A.R. Folsom. 1994. Familial clustering of breast and prostate cancers and risk of postmenopausal breast cancer. J. Natl. Cancer Inst. 86: 1860-1865.

Smith, L.J. 1985. Embryonic axis orientation in the mouse and its correlation with blastocyst relationships to the uterus II. Relationship from $41 / 4$ to $91 / 2$ days. J. Embryol. Exp. Morphol. 89: 15-35.

Smith, S.A., D.F. Easton, D.G.R. Evans, and B.A.J. Ponder. 1992. Allele losses in the region $17 \mathrm{q} 12-\mathrm{q} 21$ in familial breast and ovarian cancer non-randomly involve the wild-type chromosome. Nature Genet. 2: 128-131.

Soriano, P., C. Montgomery, R. Geske, and A. Bradley. 1991. Targeted disruption of the c-src proto-oncogene leads to osteopetrosis in mice. Cell 64: 693-702.

Spyropoulos, D.D. and M.R. Capecchi. 1994. Targeted disruption of the even-skipped gene, evx1, causes early postimplantation lethality of the mouse conceptus. Genes \& Dev. 8: 1949-1961.

Tulinius, H., V. Egilsson, G.H. Olafsdottir, and H. Sigvaldason. 1992. Risk of prostate; ovarian, and endometrial cancer among relatives of women with breast cancer. $\mathrm{Br}$. Med. I. 305: 855-857.

Yamaguchi, T.P., K. Harpal, M. Henkemeyer, and J. Rossant. 1994. Fgfr-1 is required for embryonic growth and mesoder- mal patterning during mouse gastrulation. Genes \& Dev. 8: 3032-3044.

Zhang W., R.R. Behringer, and E.N. Olson. 1995. Inactivation of the myogenic bHLH gene MRF4 results in up-regulation of myogenin and rib anomalies. Genes \& Dev. 9: 1388-1399. 


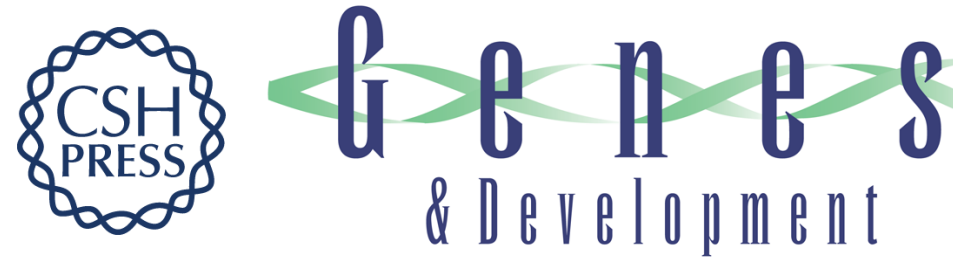

\section{Inactivation of the mouse Brca1 gene leads to failure in the morphogenesis of the egg cylinder in early postimplantation development.}

C Y Liu, A Flesken-Nikitin, S Li, et al.

Genes Dev. 1996, 10:

Access the most recent version at doi:10.1101/gad.10.14.1835

References This article cites 31 articles, 14 of which can be accessed free at:

http://genesdev.cshlp.org/content/10/14/1835.full.html\#ref-list-1

License

Email Alerting Receive free email alerts when new articles cite this article - sign up in the box at the top Service right corner of the article or click here.

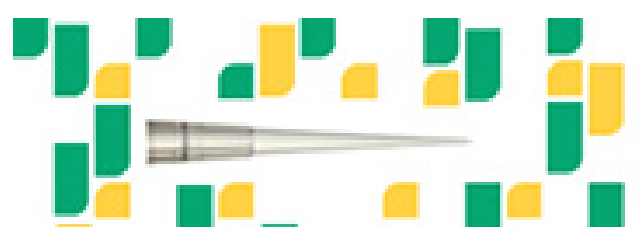

Focused on your science. 